\title{
MODEL PENGELOLAAN SUMBER DAYA ALAM UNTUK SEBESAR- BESARNYA KEMAKMURAN RAKYAT
}

\author{
Kuswandi \\ Dosen Fakultas Hukum Universitas Suryakancana
}

\begin{abstract}
ABSTRAK
Politik hukum pengelolaan sumber daya alam Indonesia adalah "merupakan sikap dan/atau perhatian Pemerintah/negara terhadap pengelolaan sumber daya alam berupa kebijakan-kebijakan yang dituangkan ke dalam Undang-Undang dan Peraturan Pemerintah, dimana hak menguasai oleh negara atas sumber daya alam sebagai landasan utama dan paling mendasar, penyelenggaraannya oleh negara untuk sebesar-besarnya kamakmuran rakyat.
\end{abstract}

Kata Kunci: Liberalisasi Ekonomi, Hak Mengusai oleh Negara, Kesejahteraan Rakyat.

\begin{abstract}
Legal political management of Indonesia's natural resources is "the attitude and/ or the attention of government/state of the management of natural resources in the form of policies as outlined in the Act and Regulation, where the rights of control by the state over natural resources as the primary basis and most fundamentally, its implementation by the state for the maximum kamakmuran people.
\end{abstract}

Keywords: $\quad$ Economic Liberalization, Right to Control by the State, Public Welfare.

\section{PENDAHULUAN.}

Kebijakan liberalisasi ekonomi dengan usaha-usaha standarisasi hukum, melalui kontrak-kontrak bisnis internasional yang dibawa oleh organisasiorganisasi asing serta investor dari negara-negara maju berawal dari upaya Indonesia untuk keluar dari krisisi ekonomi. Untuk memulihkan perekonomi nasional dan mengatasi utang yang besar akibat krisis ekonomi pada tahun 1997 yang berkepanjangan dan meluas sampai menyentuh seluruh sektor kehidupan bangsa, secara resmi Pemerintah Republik Indonesia mengundang badan moneter dunia (International Monetary Funds, IMF). IMF bersedia membantu Indonesia untuk dapat keluar dari krisis ekonomi dengan syarat Indonesia meliberalisasi pengelolaan ekonomi. 
Dua sektor energi yang diprioritaskan oleh IMF untuk diliberalisasi adalah pengelolaan Listrik dan Migas yang dapat dijadikan motor penggerak pemulihan ekonomi nasional. Di sektor Migas, Pemerintah wajib melaksanakan paket kebijakan "Konsesus Washington" melalui penandatanganan Letter of Intent (LoI) yang salah satu butir kesepkatannya adalah menghapus subsidi bahan bakar minyak (BBM) dan mengizinkan masuknya perusahaan multi nasional (Multi National Corporations, MNC) serta privatisasi beberapa Badan Usaha Milik Negara (BUMN). Perihal pengaturan privatisasi ini kemudian diterapkan melalui Peraturan Pemerintah yang mengacu pada Undang-undang No. 5 Tahun 1999 tentang Larangan Praktek Monopoli dan Persaingan Usaha Tidak Sehat (dikenal sebagai UU Anti Monopoli).

Ciri yang paling mendasar dari liberalisasi pengelolaan ekonomi adalah bahwa seluruh kegiatan pengelolaan sumber daya alam terbuka bagi Badan Usaha maupun Bentuk Usaha Tetap, membuka dan memisahkan (unbundling) seluruh sektor kegiatan pengelolaan sumber daya alam kepada pihak ketiga (termasuk perusahaan asing). Dari dasar pengertian inilah kemudian timbul bahwa siapapun boleh melakukan eksplorasi maupun eksploitasi terhadap sumber daya alam, yang terpenting adalah dapat memberikan hasil yang maksimal bagi negara. Dengan pola pikir seperti ini tidak akan pernah sampai kepada hal yang mendasar seperti kiat mempunyai "kedaulatan" atas sumber daya alam sebagaimana asas hak menguasai oleh negara. Hal tersebut menunjukan adanya penyimpangan dari amanat/arahan Undang-Undang Dasar 1945, khususnya semangat dan jiwa Pasal 33. Masalah yang utama dan mendasar adalah terkait dengan "asas hak mengusai oleh Negara" dan "produksi yang menyangkut hajat orang banyak".

Berkenaan dengan "asas hak mengusai oleh Negara", bahwa pengelolaan sumber daya alam harus dilakukan oleh Perusahan Negara yang memegang kuasa usaha pertambangan sebagai bentuk kedaulatan usaha dan apabila ada kerja sama dengan pihak ketiga (investor), kedudukannya hanya sebagai kontraktor bagi perusahaan negara. Kemudian "asas produksi yang menyangkut hajat orang banyak" juga harus dilaksanakan oleh Perusahaan Negara agar dapat menjamin pengadaan dan distribusi bagi masyarakat. 


\section{IDENTIFIKASI MASALAH.}

Tulisan ini difokuskan pada 2 (dua) isu hukum berikut ini: Pertama, mengenai politik hukum pengelolaan industri Migas dikaitkan dengan hak menguasai oleh negara atas sumber daya alam. Kedua, model pengelolaan sumber daya alam Migas untuk sebesar-bedsarnya kemakmuran rakyat.

\section{METODE PENELITIAN.}

Tipe penelitian ini adalah penelitian hukum normatif, yang dilakukan untuk mencari pemecahan permasalahan hukum, sehingga hasil penelitian ini dilakukan untuk memberikan preskripsi mengenai apa yang seyogyanya mengenai permasalahan yang diajukan serta dapat diterapkan dalam praktek hukum. Pendekatan yang digunakan dalam penelitian ini diantaranya pendekatan undangundang (statute approach), pendekatan konseptual (conceptual approach), dan pendekatan analitis (analytical approach).

Pendekatan undang-undang (statute approach) dilakukan dengan menelaah semua undang-undang dan regulasi yang bersangkut paut dengan isu hukum yang sedang dikaji.Peneliti perlu mencari ratio legis dan dasar ontologis lahirnya peraturan perundang-undang pengelolaan sumber daya alam baik Migas maupun Minerba agar dapat menangkap kandungan filosofi yang ada di belakangnya. Memahami kandungan filosofi yang ada di belakang undangundang itu, akan dapat menyimpulkan ada tidaknya benturan filosofis antara undang-undang dengan isu yang dihadapi. ${ }^{1}$

Pendekatan konseptual (conceptual approach) beranjak dari pandanganpandangan dan doktrin-doktrin yang berkembang di dalam ilmu hukum. Dengan Pendekatan konseptual (conceptual approach), peneliti akan menemukan ide-ide yang melahirkan pengertian-pengertian hukum, konsep-konsep hukum, dan asasasas hukum yang relevan dengan isu yang dihadapi. Pemahaman akan pandangan-

1 Peter Mahmud Marzuki, Penelitian Hukum, Prenada Media, Cetakan Ke-6, 2010, Jakarta, hlm. 93-94. 
pandangan dan doktrin-doktrin tersebut merupakan sandaran bagi peneliti dalam membangun suatu argumentasi hukum dalam memecahkan isu yang dihadapai. ${ }^{2}$

Pendekatan analitis (analitical approach) berguna untuk menginterpertasi secara logis, sistemis dan konsisten dimana dilakukan penelaahan data yang lebih rinci dan mendalam, Data sekunder yang berhasil dikumpulkan dalam penelitian ini, diolah, dianalisa dan ditarik kesimpulan menggunakan metode yuridis kulitatif.

\section{PEMBAHASAN.}

Secara teoritis dapat dikemukakan bahwa semua negara pada prinsipnya mempunyai tujuan yang sama yakni, memberikan kesejahteraan bagi warganya. Demikian pula Indonesia. Tujuan Negara Republik Indonesia sebagaimana yang terdapat dalam Pembukaan Undang-Undang Dasar 1945 adalah untuk memajukan kesejahteraan umum, mencerdaskan kehidupan bangsa atau dalam rumusan lainnya adalah untuk mewujudkan keadilan sosial bagi seluruh rakyat Indonesia. Rumusan demikian mempertegas bahwa secara konstitusional negara Republik Indonesia adalah penganut paradigma negara kesejahteraan (welvaarestate). Negara secara proaktif dan imperatif ikut mengusahakan keadilan dan kesejahteraan sosial bagi seluruh rakyat. Sebagai bangsa yang berdaulat, Negara Republik Indonesia mempunyai peran yang sangat luas untuk mengatur segala aspek kehidupan dalam rangka menciptakan sebesar-besarnya kemakmuran rakyat tanpa ada campur tangan dari negara manapun. Sovereignty atau Kedaulatan itu merupakan salah satu syarat berdirinya suatu negara. Salah satu unsur negara ialah adanya pemerintah yang berkedaulatan, Pemerintah dalam suatu negara harus memiliki kewibawaan (authority) yang tertinggi (supreme) dan tidak terbatas (unlimited).

Kedaulatan yang menunjuk pada kemerdekaan penuh suatu negara yang memliki wibawa tertinggi baik ke dalam maupun ke luar, dan oleh karenanya negara berkedudukan sebagai pencipta tertinggi tata hukum bagi masyarakatnya, untuk pertama kali dikemukakan oleh Jean Bodin dalam bukunya Six Livres de la

2 Ibid. 
Republique (1576). Ciri pokok dari kedaulatan negara menurut Jean Bodin adalah kekuasaan untuk menetapkan hukum bagi warga negara, secara umum atau satu demi satu. Dalam pandangannya kedaulatan itu tidak dipecah-pecah, asli dan sempurna atau tidak terbatas. Tidak terpecah-pecah karena dalam suatu negara hanya terdapat suatu kekuasaan yang tertinggi. Asli karena kekuasaan yang tertinggi tidak berasal dari kekuasaan yang lebih tinggi dan tidak terbatas karena tidak ada kekuasaan yang lebih tinggi yang dapat membatasi kekuasaan itu. ${ }^{3}$

Selanjutnya berbicara mengenai konsep tentang kekuasaan tertinggi yang biasa disebut kedaulatan (sovereignty) pada umumnya dikaitkan dengan pengertian-pengertian yang berkembang dalam sejarah, silih berganti satu samalain. Namun, dapat disimpulkan bahwa sejarah pengertian umat manusia tentang kekuasaan tertinggi atau kedaulatan mencakup lima konsepsi, yaitu: Teori Kedualatan Tuhan; Teori Kedaulatan Raja; Teori Kedaulatan Hukum; Teori Kedaulatan Rakyat; dan Teori Kedaulatan Negara.

Kedaulatan Indonesia sebagai negara yang merdeka dirumuskan dalam UUD 1945 yang menggabungkan konsep kedaulatan rakyat, kedaulatan hukum dan kedaulatan Tuhan secara sekaligus. ${ }^{4}$ Pasal 1 ayat (2) menyatakan, "Kedaulatan berada di tangan rakyat dan dilaksanakan menurut undang-undang dasar". Ketentuan ini mencerminkan bahwa UUD 1945 menganut kedaulatan rakyat atau demokrasi yang berlandaskan undang-undang dasar atau "constitutional democracy". Sedangkan Pasal 1 ayat (3) menegaskan, "Negara Indonesia adalah negara hukum". Inilah yang dimaksud dengan paham kedaulatan hukum yang pada pokoknya menganut prinsip supremasi hukum. Namun bersamaan dengan itu, gagasan kedaulatan Tuhan juga diakui dalam UUD 1945. Pertama, Pembukaan UUD 1945 mengakui bahwa perjuangan kemerdekaan Indonesia dapat berhasil "Atas berkat Rahmat Allah Yang Maha Kuasa..."; Kedua, Pembukaan UUD 1945 juga menyatakan bahwa "kemerdekaan ... Negara Republik Indonesia yang berkedaulatan rakyat berdasarkan Ketuhanan Yang

3 Moh. Kusnardi, Pengantar Hukum Tata Negara Indonesia, Sastra Hudaya, Jakarta, 1976, hlm. 123.

4 Jimly Asshiddiqie, Pokok-Pokok Hukum Tata Negara Indonesia, Bhuana Ilmu Populer, Jakarta, 2007, hlm. 148. 
Maha Esa, ...”; Ketiga, Pasal 9 ayat (1) dan (2) UUD 1945 menentukan bahwa sebelum memangku jabatannya setiap Presiden dan/atau Wakil Presiden diharuskan bersumpah atau berjanji dengan menyatakan "Demi Allah" (untuk sumpah).

Kemudian dalam UUD 1945, kedaulatan sebagai konsep kekuasaan yang tertinggi tidak hanya memiliki arti politis, tetapi juga ekonomis dan sosial. Bab XIV UUD 1945 sengaja diberi judul "Perekonomian Nasional dan Kesejahteraan Sosial". Di dalamnya terdapat ketentuan Pasal 33, misalnya, dalam ayat (3) menegaskan bahwa, "Bumi dan air dan kekayaan alam yang terkandung di dalamnya dikuasai oleh negara dan dipergunakan untuk sebesar-besarnya kemakmuran rakyat". Pasal 33 ayat (2) menegaskan pula bahwa, "Cabang-cabang produksi yang penting bagi negara dan yang menguasai hajat hidup orang banyak dikuasai oleh negara". Negara Indonesia sebagai representasi warganegaranya harus benar-benar mewakili kepentingan segenap rakyat yang memiliki kedaulatan atau kekuasaan tertinggi atas sumber-sumber ekonomi kekayaan alam Indonesia. ${ }^{5}$ Sedangkan menurut J.J. Rousseau, kekuasaan negara sebagai suatu badan atau organisasi rakyat bersumber dari hasil perjanjian masyarakat yang esensinya merupakan suatu bentuk kesatuan yang membela dan melindungi kekuasaan bersama, kekuasaan pribadi dan milik setiap individu. ${ }^{6}$

Sesuai dengan kedua teori di atas, maka secara teoritis kekuasaan negara atas sumber daya alam bersumber dari rakyat yang dikenal dengan bangsa. Negara dalam hal ini dipandang sebagai yang memiliki karakter sebagai suatu lembaga masyarakat umum, sehingga kepadanya diberikan wewenang atau kekuasaan untuk mengatur, mengurus dan memelihara (mengawasi) pemanfaatan seluruh potensi sumber daya alam yang ada dalam wilayahnya secara intensif. Dalam hal kewenangan atau kekuasaan untuk mengatur, mengurus dan memlihara (mengawasi) pemanfaatan seluruh potensi sumber daya alam dituangkan dalam bentuk politik hukum. Politik hukum pengelolaan sumber daya alam baik Migas maupun Minerba Indonesia adalah "merupakan sikap dan/atau perhatian

5 Ibid, hlm. 152.

6 R. Wiratno dkk.,Ahli-Ahli Pikir Besar tentang Negara dan Hukum, PT. Pemabngunan, Jakarta,1985, hlm. 176.

Vol. I No. 02 Edisi Juli-Desember 2015. 
Pemerintah/negara terhadap pengelolaan Migas/Minerba berupa kebijakankebijakan yang dituangkan ke dalam Undang-undang dan Peraturan Pemerintah, dimana hak menguasai oleh negara atas sumber daya alam sebagai landasan utama dan paling mendasar, penyelenggaraannya oleh negara untuk tujuan sebesar-besar kemakmuran rakyat". ${ }^{7}$

Dalam pengelolaan Sumber Daya Alam Negara harus mempertimbangkan keadilan generasi dalam menyusun regulasi yang mengatur pengelolaan sumber daya alam, dalam arti kekayaan sumber daya alam yang dimanfaatkan harus memperhatikan daya dukung alam dan kemanfaatan dalam rangka kelestarian alam untuk kemanfaatan generasi berikutnya. Prinsip dalam pengelolaan sumber daya alam (SDA) memperhatikan dan mempertimbangkan prinsip konservasi, sumber daya alam boleh dikelola tetapi tidak menimbulkan kerusakan dan pencemaran lingkungan. Daya dukung alam menjadi pertimbangan utama agar terwujudnya keadilan generasi dalam pemanfaatan sumber daya alam. Pemanfaatan dan pengelolaan lingkungan hidup khususnya sumber daya alam agar memperhatikan dengan ekosistem alamiah (internal ecosystem) dan ekosistem buatan (artificial ecosystem). Hal ini agar proses pembangunan atau proses pemanfaatan sumber daya alam sesuai dengan pembangunan berwawasan lingkungan. Komponen penting yang menjadi fondasi pembangunan landasan hukum dan politik pengelolaan sumber daya alam terdiri dari: a) Kepemilikan Kekayaan Alam; b) Penguasaan Oleh Negara; dan c) Kewenangan Perusahaan Negara dalam pengusahaan sumber daya alam sampai kepada prinsip kerjasama dengan pihak ketiga (utamanya denga pihak asing termasuk batas kewenangan yang diberikan kepada pihak asing).

Kepemilikan kekayaan sumber daya alam tunduk pada pengaturan hukum pertambangan yang dikenal dengan Kuasa Mineral (Mineral Rights), hak atas Kuasa Pertambangan (Mining Rights) dan hak atas Kuasa Usaha Pertambangan (Economic Rights). Kuasa Mineral merupakan penguasaan Negara atas kekayaan alam yang terkandung dalam suatu wilayah negara sebagai bagian integral dari

7 Suyitno Patmosukismo, Migas Politik, Hukum dan Industri, Fikahati Aneska, Jakarta, 2011, hlm. 157.

Vol. I No. 02 Edisi Juli-Desember 2015. 
kedaulatanwilayah; Kuasa Pertambangan merupakan wewenang dalam pengaturan dan pengawasan pelaksanaan kegiatan pertambangan; dan Kuasa Usaha Pertambangan merupakan wewenang untuk melakukan pengendalian dan pengelolaan usaha.

Prinsip hak menguasai dari Negara terhadap kekayaan alamnya juga diakui dalam hukum internasional sebagai berikut:

1. Resolusi Majelis Umum PBB, 21 Desember 1952 tentang prinsip penentuan nasib sendiri di bidang ekonomi setiap negara (economic selfdetermination) yang menegaskan hak setiap negara untuk memanfaatkan secara bebas kekayaan alamnya. ${ }^{8}$

2. Resolusi Majelis Umum PBB, 14 Desember 1962, 25 November 1966 dan 17 Desember 1973 yang memperluas ruang lingkup peinsip hak menuasai permanen (permanent sovereignty) terhadap kekayaan alam di dasar laut dan tanah di bawahnya dan di perairan laut yang masih berada dalam yurisdiksi nasional suatu negara. ${ }^{9}$

3. Resolusi Majelis Umum PBB Tahun 1974 dan Deklarasi tentang pembentukan Tata Ekonomi Indonesia Baru dan Program Hak-hak Ekonomi dan Kewajiban Negara (Charter of Economic Rights and Duties of State) Tahun 1974 menegaskan kembali hak menguasai dari negara untuk mengawasi kekayaan alamnya guna meningkatkan pertumbuhan ekonomi. $^{10}$

4. Covenant on Economic, Social and Cultural Rights (Pasal 1) dan Covenant and Civil Political Right (Pasal 1) tanggal 16 Desember 1966 menegaskan hak suatu negara untuk memanfaatkan secara bebas kekayaan alamnya.

Selanjutnya penataan kembali politik hukum pengelolaan sumber daya alam nasional harus konsisten dan konsekuen terhadap arahan UUD 1945 sebagaimana diuraikan di atas, dengan landasan bahwa sumber daya alam adalah

8 Starke, JG., Introdiction to International Law, $10^{\text {th }}$ edition, Butterworth, London, 1989, hlm. 121.

9 Huala Adolf, Aspek-aspek Negara dalam Hukum Internasional, edisi revisi, Raja Grafindo Persada, Jakarta, 2002, hlm. 53-54.

10 Parry and Grant, et all., Encyclopedic Dictionary of International Law, Oceana Publication Inc., New York, 1986. hlm. 290. 
sumber daya yang strategis dan mempunyai fungsi yang amat penting untuk membangun masyarakat adil dan makmur, merupakan kekayaan nasional yang hanya diusahakan oleh negara dan pengusahaannya hanya dilaksanakan oleh perusahaan negara. Dan apabila ada kerjasama dengan pihak ketiga (nasional/asing), statusnya hanya sebagai kontraktor bagi prusahaan negara, karena hanya melalui pengelolaan perusahaan negara yang dimiliki oleh Negara, upaya mendukung terealisirnya kesejahteraan dapat diwujudkan.

Kemudian selain landasan sebagaimana disampaikan di atas, ada berbagai tatanan yang harus menjadi perhatian dalam penyususnannya, yakni:

1. Bahwa industri pertambangan baik Migas maupun Minerba merupakan cabang-cabang produksi yang amat penting bagi negara dan menguasai hajat hidup orang banyak baik langsung maupun tidak;

2. Bahwa Migas maupun Minerba mempunyai arti yang khusus untuk pertahanan nasional;

3. Bahwa persoalan-persoalan mengenai Migas maupun Minerba mengandung aspek-aspek internasional;

4. Bahwa hak menguasai oleh negara harus sesuai dengan tujuan Negara Kesejahteraan sebagaimana arahan UUD 1945, Pasal 33 ayat (3). Keterkaitan dengan hak penguasaan negara dengan sebesar-besar kemakmuran rakyat akan mewujudkan kewajiban negara antara lain yang utama adalah bahwa segala bentuk pemanfaatan sumber daya alam harus secara nyata meningkatkan kemakmuran dan kesejahteraan.

5. Bahwa pengelolaan sumber daya alam Migas maupun Minerba harus dapat dikembangkan yang terbaik untuk kepentingan nasional, sebagaimana dinyatakan dalam teori hukum pembangunan Mochtar Kusumaatmadja bahwa dalam pengembangan hukum ada hukum netral dan tidak netral. Berkenaan dengan pengelolaan Migas maupun Minerba penulis berpendapat masuk kategori hukum netral, dengan demikian untuk mendapatkan yang terbaik dapat melakukan perbandingan dengan konsep/kebijakan pengelolaan Migas maupun Minerba di berbagai negara 
tanpa harus meninggalkan nilai-nilai yang terkandung dalam jati diri bangsa.

Dengan landasan politik hukum pengelolaan sumber daya alam Migas dan Minerba sebagaimana diuraikan di atas, penulis berpendapat agar segera diambil langkah konkrit untuk melakukan rekonseptualisasi terhadap peraturan perundang-undangan Pertambangan yang mempunyai Misi meningkatkan kemandirian dan ketahanan nasional guna mampu mendukung pembangunan nasional berkelanjutan. Untuk mewujudkan Misi tersebut, peraturan perundangundangan Pertambangan masa depan perlu ditopang "lima pilar", yakni:

\section{Pancasila.}

Selain sebagai falsafah berbangsa dan bernegara, Pancasila yang merupakan sumber dari segala sumber hukum, harus dijadikan acuan bagi setiap langkah kebijakan terkait dengan pengelolaan industri Pertambangan Nasional.

\section{UUD 1945.}

Pada dasarnya peraturan perundang-undangan tentang pengelolaan sumber daya alam harus "kembali ke UUD 1945" dan lebih spesifik melaksanakan semangat dan jiwa yang terkandung dalam Pasal 33 dengan konsisten dan konsekuen; bahwa pengelolaan kekayaan alam tidak pernah terlepas dari makna sosial. Politik dan ekonomi yang berarti kemakmuran bagi seluruh rakyat Indonesia.

\section{Negara Kesatuan Republik Indonesia (NKRI).}

Pengertian negara kepulauan dengan semboyan "Bhineka Tunggal Ika" yang berarti "Kesatuan dalam Keanekaragaman".Agar semboyan ini tidak hanya mengandung tekad persatuan bangsa, namun juga merupakan "komitmen" seluruh komponen bangsa melaksanakan pembangunan bagi terciptanya Negara Kesejahteraan.

\section{Politik Keberpihakan Pemerintah Republik Indonesia.}

Politik keberpihakan Pemerintah RI dimaksudkan untuk ditujukan kepada Perusahaan Negara (BUMN) berupa pemberian kesempatan agar menjadi besar dan kuat sehingga dapat melaksanakan fungsinya delam menyediakan energi nasional jangka panjang. 


\section{Memantapkan Fungsi Perusahaan Negara.}

Sumber daya alam Migas/Minerba sebagai kekayaan nasional yang dimiliki rakyat Indonesia seharusnyalah tidak pernah terlepas dari arti hakiki kedaulatan. Dengan penegasan ini maka wujud kedaulatan usaha menempatkan Negara sebagai pemegang kuasa mineral (mineral right), Pemerintah sebagai pemegang kuasa pertambangan (mining right), dan Perusahaan Negara (BUMN) sebagai pemegang kuasa usaha pertambangan (economic right).Dalam konteks ini, maka BUMN harus menjadi andalan mengelola sumber daya alam untuk mewujudkan kesejahteraan bagi seluruh rakyat Indonesia, sebagaimana cita-cita yang telah dirumuskan oleh para pendiri bangsa dalam pembukaan UUD 1945.

Sehingga dengan demikian terwujudnya kesejahteraan dan keadilan sosial diharapkan akan menimbulkan perasaan tentram dalam batin para warga masyarakat. Dengan terpeliharanya perasaan tentram itu, maka ketertiban akan mempunyai akar yang kuat, ${ }^{11}$ sehingga berbagai konflik sosial yang terjadi di tanah air dapat dieliminir. Semoga.

\section{PENUTUP.}

\section{A. Kesimpulan.}

Kedaulatan ialah kekuasaan penuh dan tertinggi suatu Negara untuk mengatur sendiri wilayahnya tanpa campur tangan dari pemerintah Negara lain atapun organisasi-organisasi internasional. Konsep kedaulatan sebagai kekuasaan tertinggi yang terdapat dalam UUD 1945 selain memiliki arti politis juga memiliki arti ekonomis dan sosial sebagaimana yang dirumuskan dalam Bab XIV UUD 1945 yang secara sengaja diberi judul "Perekonomian Nasional dan Kesejahteraan Sosial". Berdasarkan Pasal 33 ayat (2) dan (3) dalam meneglola sumber daya alam Migas/Minerba nasional menegaskan bahwa Negara Indonesia sebagai representasi warganegaranya harus benar-benar mewakili kepentingan segenap rakyat yang memiliki kedaulatan atau kekuasaan tertinggi atas sumber-sumber ekonomi kekayaan alam Indonesia. Kekuasaan negara atas sumber daya alam

11 Soediman Kartohadiprodjo, Pancasila Sebagai Pandangan Hidup Bangsa Indonesia, Bandung, 2011, hlm. xi. 
bersumber dari rakyat yang dikenal dengan bangsa, yang kepadanya diberikan wewenang atau kekuasaan untuk mengatur, mengurus, memelihara, dan mengawasi pemanfaatan seluruh potensi sumber daya alam yang ada di seluruh wilayah Indonesia.

Kemudian komponen penting yang harus menjadi fondasi pembangunan landasan hukum dan politik pengelolaan sumber daya alam Migas/Minerba nasional yang menceminkan hak menguasai oleh Negara atas sumber daya alam Migas/Minerba untuk terwujudnya kedaulatan nasional adalah: a) Kepemilikan Kekayaan Alam; b) Penguasaan Oleh Negara; c) Kewenangan Perusahaan Negara dalam pengusahaan Migas/Minerba sampai kepada prinsip kerjasama dengan pihak ketiga (utamanya dengan pihak asing).

\section{B. Saran.}

Model pengelolaan Migas dan Minerba masa depan seyogianya mengedepankan Kepentingan Nasional yang dilandasi semangat nasionalisme dalam pengertian yang luas, dengan Visi mewujudkan tujuan Negara sebagaimana yang terdapat dalam pembukaan UUD 1945 alinea 4 serta harus mengemban Misi membangun kemandirian dan ketahanan energi nasional guna mendukung pembangunan nasional berkelanjutan. Untuk mewujudkan Misi tersebut, peraturan perundang-undangan pengelolaan sumber daya alam masa depan perlu ditopang "lima pilar", yakni: 1. Pancasila; 2. UUD 1945; 3. NKRI; 4. Politik Keberpihakan Pemerintah RI; dan 5. Memantapkan Fungsi Perusahaan Negara.

Pengelolaan sumber daya alam masa depan seyogyanya berlandaskan kepada bahwa kepemilikan kekayaan alam tunduk pada pengaturan hukum pertambangan yang dikenal dengan hak atas Kuasa Mineral (Mineral Rights), Hak Atas Kuasa Pertambangan (Mining Rights), dan Hak Atas Kuasa Usaha Pertambangan (Economic Rights). Kuasa mineral merupakan penguasaan atas kekayaan alam yang terkandung dalam suatu wilayah negara sebagai bagian integral dari kedaulatan wilaya; kuasa pertambangan merupakan wewenang dalam pengaturan dan pengawasan pelaksanaan kegiatan pertambangan; dan kuasa usaha pertambangan merupakan wewenang untuk melakukan pengendalian dan pengelolaan usaha. 


\section{A. Buku.}

\section{DAFTAR PUSTAKA}

Bagir Manan, Teori dan Politik Konstitusi, Fakultas Hukum UII Press, Yogyakarta, 2003.

Huala Adolf, Aspek-Aspek Negara dalam Hukum Internasional, edisi revisi, Raja Grafindo Persada, Jakarta, 2002.

Jimly Asshiddiqie, Pokok-Pokok Hukum Tata Negara Indonesia, Bhuana Ilmu Populer, Jakarta, 2007.

Mahfud MD, Membangun Politik Hukum, Menegakan Konstitusi, LP3ES, Jakarta, 2006. , Politik Hukum Indonesia, Pustaka LP3ES, Jakarta, 2006.

Mariam Budiarjo, Dasar-Dasar Ilmu Politik, Gramedia Pustaka Utama, Jakrta, 1996.

Moh. Kusnardi, Pengantar Hukum Tata Negara Indonesia, Sastra Hudaya, Jakarta, 1976.

Peter Mahmud Marzuki, Penelitian Hukum, Prenada Media, Cetakan Ke-6, 2010, Jakarta.

R. Wiratno dkk.,Ahli-Ahli Pikir Besar tentang Negara dan Hukum, PT. Pemabngunan, Jakarta, 1985.

Satjipto Rahardjo, Ilmu Hukum, Bandung, 1982.

Soediman Kartohadiprodjo, Pancasila Sebagai Pandangan Hidup Bangsa Indonesia, Bandung, 2011.

Sondang P. Siagian, Administrasi Pembangunan, Konsep, Dimensi dan Strateginya, Bumi Aksara, Jakarta, 2005.

Starke, JG, Introdiction to International Law, $10^{\text {th }}$ edition, Butterworth, London, 1989.

Suyitno Patmosukismo, Migas Politik, Hukum dan Industri, Fikahati Aneska,Jakarta, 2011.

Utrecht, Pengantar Ilmu Administrasi Negara Indonesia, Fakultas Hukum dan Masyarakat, UNPAD, Bandung, 1960. 


\section{B. Peraturan Perundang-undangan.}

Undang-Undang Dasar 1945;

Undang-Undang Nomor 37/Prp/1960 Tentang Pertambangan Umum;

Undang-Undang Nomor 44/Prp/1960 Tentang Migas;

Undang-Undang Nomor 8 Tahun 1971 Tentang Pertamina;

Undang-Undang Nomor 5 Tahun 1999 Tentang Larangan Praktek Monopoli dan Persaingan Usaha Tidak Sehat;

Undang-Undang Nomor 22 Tahun 2001 Tentang Pengelolaan Sumber Daya Minyak dan Gas;

Undang-Undang Nomor 4 Tahun 2009 Tentang Mineral dan Batu Bara;

Peraturan Pemerintah Nomor 42 Tahun 2002 Tentang BP Migas;

Keputusan Presiden Nomor 67 Tahun 2001 Tentang BPH Migas;

Putusan Mahkamah Konstitusi Nomor 36/PUU-X/2012 Tentang Pembubaran BP Migas.

\section{Jurnal, Makalah, Internet, Koran, Majalah, Dan Lain-lain.}

B.Aref Sidharta, Filsafat Hukum Pancasila, Materi Kuliah Program Doktor Ilmu Hukum Universitas Katolik Parahyangan, Bandung, 2010.

Parry and Grant, et all., Encyclopedic Dictionary of International Law, Oceana Publication Inc., New York, 1986. 